Materiales de Construcción

Vol. 68, Issue 330, April-June 2018, e158

ISSN-L: 0465-2746

https://doi.org/10.3989/mc.2018.04717

\title{
Influence of bagasse ash and recycled concrete aggregate on hardened properties of high-strength concrete
}

\author{
P. Rattanachu ${ }^{\mathrm{a}}$, I. Karntong ${ }^{\mathrm{a}}$, W. Tangchirapat ${ }^{\mathrm{a}} \bowtie$, C. Jaturapitakkul ${ }^{\mathrm{a}}$, P. Chindaprasirt ${ }^{\mathrm{b}}$ \\ a. Department of Civil Engineering, Faculty of Engineering, King Mongkut's University of Technology Thonburi (KMUTT), \\ (Bangkok, Thailand) \\ b. Sustainable Infrastructure Research and Development Center, Department of Civil Engineering, Faculty of Engineering, \\ Khon Kaen University, (Khon Kaen, Thailand)
}

$\triangle$ weerachart.tan@kmutt.ac.th

Received 20 April 2017

Accepted 11 October 2017

Available on line 26 April 2018

\begin{abstract}
This research aimed to use of bagasse ash as a cement replacement in high-strength recycled aggregate concrete (HS-RAC). Crushed limestone was replaced with 100\% recycled concrete aggregate (RCA) and the ground bagasse ash (GBA) was used to partially replace ordinary Portland cement (OPC) at 20, 35 and $50 \%$ wt of binder to cast HS-RAC. The results indicated that the replacing of crushed limestone with RCA had a negative impact on the properties of the concrete. Increasing the amount of GBA in HS-RAC resulted in a decrease in density and an increase in the volume of permeable pore space. The concrete mixtures prepared with $20 \%$ wt GBA replacement of OPC promoted greater the compressive strength than the conventional concrete (CT concrete) at 90 days or more. HS-RAC with GBA (up to 50\%) was more durable in terms of chloride ion penetration resistance, although it had lower compressive strength than the CT concrete.
\end{abstract}

KEYWORDS: Concrete; Aggregate; Compressive strength; Durability; Chloride

Citation/Citar como: Rattanachu, P.; Karntong, I.; Tangchirapat, W.; Jaturapitakkul, C.; Chindaprasirt, P. (2018) Influence of bagasse ash and recycled concrete aggregate on hardened properties of high-strength concrete. Mater. Construcc. 68 [330], e158. https://doi.org/10.3989/mc.2018.04717

RESUMEN: Influencia de la ceniza de bagazo y los áridos de hormigón reciclado en las propiedades de endurecimiento de hormigones de alta resistencia. En esta investigación se utilizó ceniza de bagazo como sustituto del cemento en hormigón de alta resistencia con áridos reciclados (HS-RAC). La piedra caliza fue sustituida por un árido $100 \%$ reciclado de hormigón y la ceniza de bagazo molida (GBA) en diferentes porcentajes (20, 35 y $50 \%$ en peso del material cementante) fue utilizada para reemplazar parcialmente al cemento Portland para producir hormigón de tipo HS-RAC. Los resultados indicaron que la sustitución de la piedra caliza molida por áridos de hormigón reciclado tiene un efecto negativo en las propiedades del hormigón. Aumentar la cantidad de GBA en el HS-RAC redujo la densidad e incrementó el volumen del espacio de los poros permeables. Las mezclas de hormigón preparadas reemplazando $20 \%$ en peso del cemento Portland por ceniza de bagazo molida presentaron mayor resistencia a la compresión que el hormigón convencional a los 90 días o más. El HS-RAC con GBA (hasta 50\%) tuvo una durabilidad mayor que el hormigón convencional en términos de resistencia a la penetración de iones de cloruro, a pesar de tener una menor resistencia a la compresión.

PALABRAS CLAVE: Hormigón; Árido; Resistencia a la compresión; Durabilidad; Cloruros

ORCID ID: P. Rattanachu (http://orcid.org/0000-0001-9231-0046); I. Karntong (http://orcid.org/0000-0002-01348485); W. Tangchirapat (http://orcid.org/0000-0002-4917-1367); C. Jaturapitakkula (http://orcid.org/0000-0002-8785947X); P. Chindaprasirt (http://orcid.org/0000-0003-1062-3626)

Copyright: (C) 2018 CSIC. This is an open-access article distributed under the terms of the Creative Commons Attribution 4.0 International (CC BY 4.0) License. 


\section{INTRODUCTION}

High-strength concrete (HS-C) is used extensively in current civil engineering projects, since most of this concrete's properties are more efficient than those of ordinary-strength concrete. For highrise constructions, HS-C helps to decrease the size of structural concrete members, such as columns and beams, which leads to a decrease in the total volume of concrete and reinforcement required and to the associated reduction in the cost of construction projects. Currently, pozzolanic materials are popularly used as a substitute for ordinary Portland cement (OPC) in HS-C mixtures. These materials are commonly used to strengthen the concrete by pozzolanic reaction and improve the quality of the concrete. Experimental results obtained by Sata et al. (1) suggested that pozzolanic materials could be used as an OPC replacement to produce HS-C, there being no negative impact on the mechanical properties of the concrete. Similarly, Nath and Sarker (2) reported that fly ash could improve the durability of HS-C with respect to chloride penetration resistance and drying shrinkage. Likewise, HS-C with palm oil fuel ash was of good quality and had increased resistance to sulfate attack (3).

The increase in new construction projects has resulted in a critical shortage of natural aggregate (NA). At the same time, a large amount of waste concrete from the demolition of buildings and old structures has resulted in an increase in the amount of trash entering landfills. Thus, several researchers have studied the use of demolition waste concrete as a recycled concrete aggregate (RCA) in new concrete. Katz (4) reported that concrete made with NA was stronger than concrete made with $100 \%$ RCA at a similar water to cement ratio of concrete, which resulted in decreased compressive strength, flexural strength, and splitting tensile strength. Similarly, Prince and Singh (5) reported that the bond strength of steel reinforcement in concrete containing RCA tended to decrease as RCA replacement levels increased. In addition, many researchers suggested that the using of RCA to replace NA had a negative effect on the durability of concrete (6-9). As reported in the literature, the weakness and high porosity of recycled aggregate, which is poorer than crushed limestone $(10-12)$, results in a lower quality concrete. However, recycled concrete can also be used as the aggregate for new concrete if its quality is been improved $(12,13)$. Similarly, the concrete mixing method and the use of a pozzolanic material leads to an increase in the quality of concrete containing RCA $(14,15)$.

Currently, pozzolanic materials, e.g., fly ash, palm oil fuel ash and rice husk ash, are widely used as a cement replacement in concrete and can improve the quality and durability properties of concrete (16-20). Likewise, bagasse ash (BA), a by-product acquired from burning bagasse for an electricity generation power plant at a sugar factory, has been ground to have high fineness and used as a pozzolanic material in concrete $(21,22)$. Chusilp et al. (23) indicated that BA could be used to partially replace OPC at a rate as high as $30 \%$ wt of binder and that the resulting the compressive strength at 28 and 90 days could be higher than those of concrete without BA. Rukzon and Chindaprasirt (24) found that incorporating $10-30 \%$ of ground BA improved the compressive strength of concrete and made it stronger than that of control concrete. The concrete with BA is of good quality with diminished porosity, improved chloride penetration resistance, and increased resistance to sulfate attack $(25,26)$.

In fact, RCA offers the potential for use as an aggregate in new concrete. However, from previous research, only a few experimental data on the use of RCA in concrete, especially in HS-C are available. In addition, many reports confirmed that the use of pozzolanic material, in many aspects, enhances the quality of concrete. Likewise, BA, a highly reactive pozzolan with a small particle size, could thus improve the properties of concrete. However, the studies on the use of BA in HS-C containing RCA had not been reported. Therefore, in this research, BA was ground to a small particle size and was used to partially substitute OPC at 20 to $50 \%$ wt of cementitious material to improve the quality of HS-C containing RCA. The density, volume of permeable pore space, compressive strength, chloride ion penetration depth, and chloride migration coefficient of the HS-C containing recycled coarse aggregate were examined, and the results were compared with those of conventional HS-C. Furthermore, the findings of this study will encourage further research on the development of by-product materials from industry including RAC and BA. This will ultimately lead to an increase in their use and be of benefit to the environment.

\section{MATERIALS AND METHODS}

\subsection{Materials}

\subsubsection{Binder Materials}

Ordinary Portland cement (OPC), which was the main cementitious material for this study, was used to cast the HS-C specimens. The physical properties and the chemical components of OPC are summarized in Tables 1 and 2, respectively.

Additionally, bagasse ash (BA), a by-product acquired from burning bagasse for an electricity generation power plant at a sugar factory in Ratchaburi province, Thailand (as shown in Figure 1), was used in this study. The literature indicates that BA with elevated fineness could be a good pozzolanic material in concrete $(21,22)$. 
TABLE 1. Physical properties of the cementitious materials

\begin{tabular}{lcc}
\hline Materials & $\begin{array}{c}\text { Specific } \\
\text { gravity }\end{array}$ & $\begin{array}{c}\text { Retained on a } \\
\text { sieve No. 325 } \\
\text { (\%) }\end{array}$ \\
\hline Ordinary Portland cement (OPC) & 3.15 & N/A \\
Ordinary bagasse ash (OBA) & 1.92 & 60.1 \\
Ground bagasse ash (GBA) & 2.27 & 0.7 \\
\hline
\end{tabular}

TABLE 2. Chemical compositions of ordinary Portland cement (OPC) and ground bagasse ash (GBA)

\begin{tabular}{llcc}
\hline & & $\begin{array}{c}\text { Ordinary } \\
\text { Portland } \\
\text { cement } \\
\text { Chemical composition }(\%)\end{array}$ & $\begin{array}{c}\text { Ground } \\
\text { bagasse } \\
\text { ash } \\
(\mathbf{G B A})\end{array}$ \\
\hline Silicon dioxide & $\left(\mathrm{SiO}_{2}\right)$ & 20.1 & 72.0 \\
Aluminum oxide & $\left(\mathrm{Al}_{2} \mathrm{O}_{3}\right)$ & 4.8 & 4.1 \\
Ferric oxide & $\left(\mathrm{Fe}_{2} \mathrm{O}_{3}\right)$ & 3.5 & 3.0 \\
Calcium oxide & $(\mathrm{CaO})$ & 65.5 & 5.9 \\
Magnesium oxide & $(\mathrm{MgO})$ & 1.3 & 1.1 \\
Sulfur trioxide & $\left(\mathrm{SO}_{3}\right)$ & 2.7 & 1.2 \\
Phosphorus pentoxide & $\left(\mathrm{P}_{2} \mathrm{O}_{5}\right)$ & 0.1 & 1.2 \\
Potassium oxide & $\left(\mathrm{K}_{2} \mathrm{O}\right)$ & 0.3 & 4.0 \\
Loss on ignition & $(\mathrm{LOI})$ & 1.7 & 7.5 \\
\hline
\end{tabular}

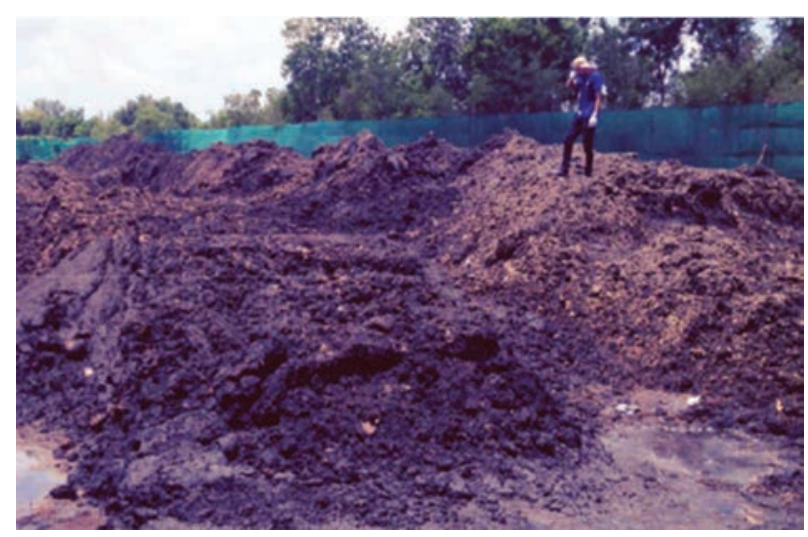

FIGURE 1. Disposal area of bagasse ash.

Thus, the original bagasse ash (OBA), for which the particles retained on a No. 325 sieve $(45 \mu \mathrm{m})$ were $60.1 \%$ wt (with a specific gravity, SG, of 1.92 ), was ground until the particles retained on a No. 325 sieve were $0.7 \%$ wt (with a SG of 2.27 ) to improve its reactivity. The ground bagasse ash (GBA) particles measured from 0.3 to $50 \mu \mathrm{m}$ and had a median particle size $\left(\mathrm{d}_{50}\right)$ of $7.5 \mu \mathrm{m}$ as shown in Figure 2. The chemical constituents of GBA were analyzed by X-Ray Fluorescence spectrometry (as shown in Table 2). The principal chemical constituent of GBA was $72.0 \%$ wt $\mathrm{SiO}_{2}$ while the loss on ignition

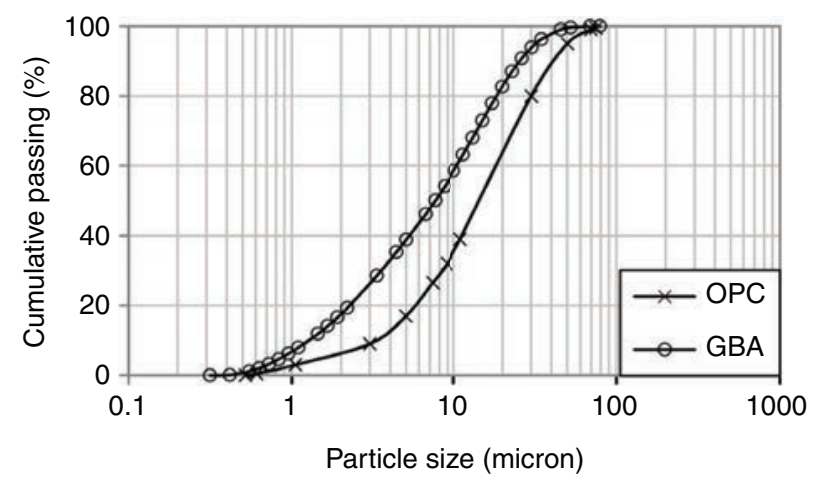

Figure 2. Particle size distributions of OPC and GBA.

(LOI) was $7.5 \%$. GBA was used as a pozzolanic material to replace OPC in HS-RAC.

\subsubsection{Aggregates}

Crushed limestone from a natural source with a grain size distribution between 4.75 and $12.50 \mathrm{~mm}$ by sieving was used as a coarse aggregate to cast conventional HS-C. The fineness modulus (FM) was found to be 6.40 , the SG was 2.71 , the crushing value was $22.0 \%$, the water absorption was $0.57 \%$, the void content was $45.1 \%$, and the unit weight was $1480 \mathrm{~kg} / \mathrm{m}^{3}$. The particle size distribution of the crushed limestone is shown in Figure 3.

Recycled concrete aggregate (RCA) was obtained by using a jaw crusher to crush rejected HS-C columns (with a compressive strength of approximately $50 \mathrm{MPa}$ ), as shown in Figure 4. The crushed column concrete aggregates were graded, selecting a 4.75 to $12.50 \mathrm{~mm}$ fraction by sieve, and used as a recycled coarse aggregate. Figure 3 shows the particle size distributions of the recycled coarse aggregate compared with the size distribution requirements in ASTM C 33 (27).

Many researchers have reported that the old cement paste and mortar attached to the surface of

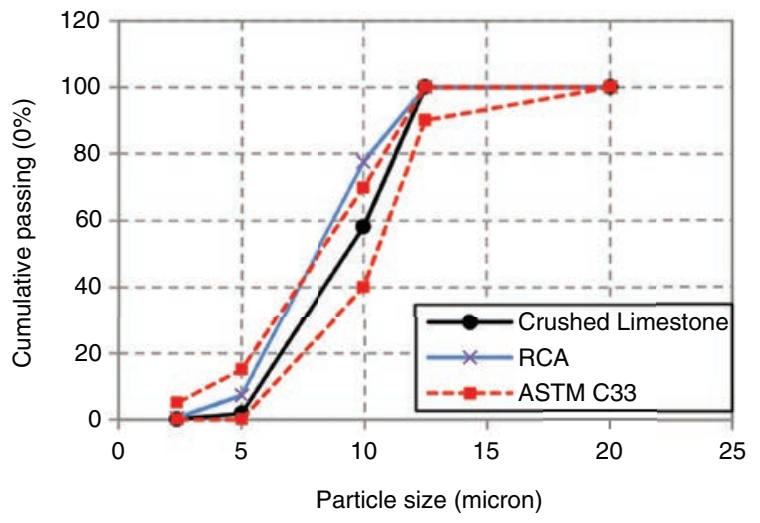

FIGURE 3. Particle size distributions of coarse aggregates. 
(a)

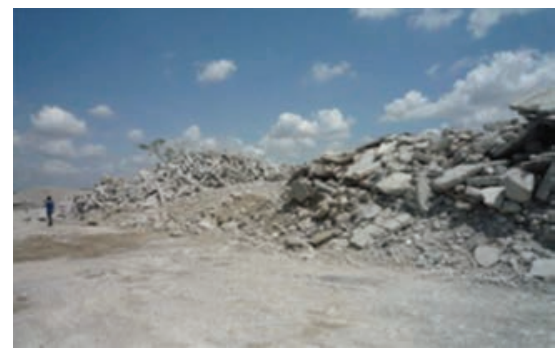

(b)

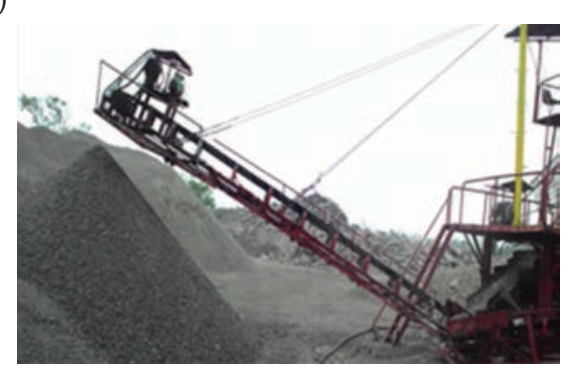

FIGURE 4. Disposal area of recycled concrete aggregate.

TABle 3. Physical properties of the sand, crushed limestone, and recycled coarse aggregates

\begin{tabular}{lccc}
\hline Properties & $\begin{array}{c}\text { River } \\
\text { Sand }\end{array}$ & $\begin{array}{c}\text { Crushed } \\
\text { Limestone }\end{array}$ & $\begin{array}{c}\text { Recycled } \\
\text { Coarse } \\
\text { Aggregates }\end{array}$ \\
\hline Fineness Modulus & 2.93 & 6.40 & 6.13 \\
Specific Gravity (SSD) & 2.61 & 2.71 & 2.45 \\
Water Absorption (\%) & 0.75 & 0.57 & 5.44 \\
Moisture Content (\%) & 0.19 & 0.16 & 1.65 \\
Porosity (\%) & 1.93 & 1.55 & 12.63 \\
Crushing Value (\%) & N/A & 22.0 & 25.7 \\
Unit Weight $\left(\mathrm{kg} / \mathrm{m}^{3}\right)$ & N/A & 1480 & 1380 \\
Void Content $(\%)$ & N/A & 45.1 & 43.4 \\
\hline
\end{tabular}

the original crushed aggregate greatly influence on the quality of RCA $(10-12)$. Table 3 shows the physical properties for the crushed limestone and the RCA used in the research. The RCA had a porosity of $12.63 \%$ by volume, which was approximately 8 times higher than that of crushed limestone (which had a porosity of $1.55 \%$ by volume) due to the porosity of the cement paste and mortar, which was attached to the surface texture of the aggregate. These results indicate a higher porosity of the RCA than the crushed limestone. Additionally, the high porosity of RCA resulted in high water absorption and high moisture content. Water absorption and moisture content in the RCA were $5.44 \%$ and $1.65 \%$, respectively. These volumes are approximately 10 times higher than those of the crushed limestone, which had water absorption and moisture content of 0.57 and $0.16 \%$, respectively. In addition, the RCA had a SG of $2.45, \mathrm{FM}$ of 6.13 , crushing value of $25.7 \%$, void content of $43.4 \%$, and unit weight of $1380 \mathrm{~kg} / \mathrm{m}^{3}$.

Moreover, river sand, with an SG of 2.61, FM of 2.93 , porosity of $1.93 \%$, water absorption of $0.75 \%$ and moisture content of $0.19 \%$, was used as a fine aggregate to cast the concrete specimens.

\subsection{Mixture Proportions}

The HS-C mixture proportions are presented in Table 4. The design strength of the conventional HS-C was targeted to be approximately $60 \mathrm{MPa}$ at 28 days. The HS-C specimens were separated into two groups. The first group was the conventional concrete composed of river sand and crushed limestone. The second group was the RAC composed of river sand and RCA. GBA was used to substitute OPC at 20 to $50 \%$ wt of binder (RA20, RA35, and RA50). The crushed limestone and RCA were made saturated surface dry (SSD) by immersing them in a bucket of water for $24 \mathrm{~h}$ before mixing in the concrete. The ratio between effective water to binder of all concretes was fixed at 0.30. Following ASTM C494 (28), commercially available polycarboxylate ether polymers superplasticizers, Type A and F, were employed in the concrete mixtures to control the slump of fresh concrete at values between 150 and $200 \mathrm{~mm}$.

TABle 4. Concrete mix proportions

\begin{tabular}{|c|c|c|c|c|c|c|c|c|c|}
\hline \multirow[b]{2}{*}{ Mix } & \multicolumn{7}{|c|}{ Mix proportion $\left(\mathrm{kg} / \mathrm{m}^{3}\right)$} & \multirow[b]{2}{*}{ W/B } & \multirow[b]{2}{*}{$\underset{(\mathrm{cm})}{\text { Slump }}$} \\
\hline & OPC & GBA & $\begin{array}{c}\text { Crushed } \\
\text { Limestone }\end{array}$ & $\mathbf{R C A}^{\mathrm{a}}$ & Sand & Eff. Water & SP. $^{\mathrm{b}}$ & & \\
\hline $\mathrm{CT}$ & 560 & - & 990 & - & 750 & 170 & 1.5 & 0.30 & 15.0 \\
\hline RA & 560 & - & - & 925 & 710 & 170 & 1.5 & 0.30 & 15.5 \\
\hline RA20 & 450 & 110 & - & 890 & 710 & 170 & 2.3 & 0.30 & 17.0 \\
\hline RA35 & 365 & 195 & - & 885 & 705 & 170 & 2.8 & 0.30 & 17.0 \\
\hline RA50 & 280 & 280 & - & 880 & 700 & 170 & 3.4 & 0.30 & 15.5 \\
\hline
\end{tabular}

${ }^{\text {a }}$ Crushed limestone and RCA are in the saturated surface dry (SSD) state.

${ }^{\mathrm{b}}$ Superplasticizer was assumed to contain water at $50 \%$ by weight. 
The required superplasticizer content of HS-C is shown in Table 4. Both the CT and RA concretes required $1.5 \mathrm{~kg} / \mathrm{m}^{3}$ of superplasticizer to maintain the slump of fresh concrete at values between 150 and $200 \mathrm{~mm}$. When GBA was used to substitute OPC in HS-RAC, a higher superplasticizer dosage was needed in order to maintain the same degree of workability (150-200 mm slump). In the conditions where 20, 35 and $50 \%$ of OPC in RAC was replaced by GBA, the required superplasticizer contents were $2.3,2.8$ and $3.4 \mathrm{~kg} / \mathrm{m}^{3}$, respectively. The increase of superplasticizer dosage was due to the high porosity and high LOI value of GBA, which led to high water absorption.

This experiment used the two-stage mixing approach proportional-2 (TSMA $\mathrm{T}_{\mathrm{p}}$ ) method suggested by Tam et al. (14), witch has the following steps. First, all aggregates (both coarse and fine) and half of the binder are mixed for one minute. Second, the rest of the binder is added, and then water is added and mixed for another two minutes. The exclusive $\mathrm{TSMA}_{\mathrm{p} 2}$ procedure creates a thin film of cementitious slurry (substances from the cement with a relatively lower water to binder ratio) on the surface texture of the RCA, which is expected to penetrate the porous old mortar and fill the old cracks and voids. Therefore, the weaker link at the interface transition zone (ITZ) of concrete can be improved.

\subsection{Tests}

\subsubsection{Test for Density and Permeable Pore Space of Hardened Concrete}

At 90 days, the density and volume of the permeable pore space (\%void) of HS-C with a thickness of $50 \mathrm{~mm}$ (sawn from the middle of a $100 \times 200 \mathrm{~mm}$ cylinder of concrete) were investigated follwing to ASTM C642 (29). The ASTM C642 (29) procedure is as follows. Weigh and record the mass of the specimen after drying it in an oven at $110+5^{\circ} \mathrm{C}$ for more than $24 \mathrm{~h}\left(\mathrm{Mass}_{\mathrm{A}}, \mathrm{g}\right)$. Then, immerse all of the specimens in a boiling water for $5 \mathrm{~h}$. Determine the mass of the specimen after letting it cool via natural loss of heat for no less than $14 \mathrm{~h}$ until a final temperature between 20 and $25^{\circ} \mathrm{C}$ is achieved (Mass ${ }_{\mathrm{B}}, \mathrm{g}$ ). After that, determine the apparent mass of the specimen in tap water $\left(\operatorname{Mass}_{C}, \mathrm{~g}\right)$. The density and $\%$ void of HS-C are calculated by equations [1] and [2], respectively:

$$
\text { Density }\left(\mathrm{kg} / \mathrm{m}^{3}\right)=\left[\operatorname{Mass}_{\mathrm{A}} /\left(\operatorname{Mass}_{\mathrm{B}}-\right.\right.
$$

$$
\begin{aligned}
& \text { Volume of } \quad\left[\left(\operatorname{Mass}_{\mathrm{B}}-\text { Mass }_{\mathrm{A}}\right) /\right. \\
& \text { permeable pore } \left.=\left(\operatorname{Mass}_{\mathrm{B}}-\text { Mass }_{\mathrm{C}}\right)\right] \times \\
& \text { space (\%void) } \quad 100
\end{aligned}
$$

\subsubsection{Test for Compressive Strength}

The methodology for determining the compressive strength of concrete is from ASTM C39 (30). At 7, 28 and 90 days after casting, the average compressive strength of the three cylindrical HS-C samples (dia.100 x $200 \mathrm{~mm}$ ) was investigated, and the results of the tests could not depart more than $10.6 \%$ from their average.

\subsubsection{Test for Chloride Migration}

The chloride migration coefficient $\left(\mathrm{D}_{\mathrm{nssm}}\right)$ of concrete was measured in accordance with NT BUILD 492 (31). This method was carried out as follows: a $50 \mathrm{~mm}$ disc sawn from the (dia.100 x $200 \mathrm{~mm}$ ) concrete cylinder was placed in a setup, where it was exposed to a $0.3 \mathrm{~mol} / \mathrm{L} \mathrm{NaOH}$ solution on one side and an aqueous $10 \% \mathrm{NaCl}$ solution on the opposite side. A $60 \mathrm{~V}$ direct current power supply modified from AASHTO TP64-03 (32) was connected with the anode $(\mathrm{NaOH}$ solution) and the cathode ( $\mathrm{NaCl}$ solution). After $18 \mathrm{~h}$ of testing, the voltage was turned off, and then the specimen was split in half lengthways and the chloride ion penetration depth was measured by spraying an $\mathrm{AgNO}_{3}$ solution on the fresh fracture surface, as recommended by Otsuki et al. (33). In this experiment, the $D_{\text {nssm }}$ of all concrete specimens were investigated at 28 and 90 days. The result of $D_{\text {nssm }}$ at each age was the average of three samples and the coefficient of variation of repeatability was $9.0 \%$. The $\mathrm{D}_{\mathrm{nssm}}$ of the concrete was calculated by equation [3]:

$$
\begin{aligned}
D_{\text {nssm }}\left(\times 10^{-12} \mathrm{~m}^{2} / \mathrm{s}\right) & =\frac{0.0239(273+\mathrm{T}) \mathrm{L}}{(\mathrm{U}-2) \mathrm{t}} \\
& \left(\mathrm{x}_{\mathrm{d}}-0.0238 \sqrt{\frac{(273+\mathrm{T}) \mathrm{Lx}_{\mathrm{d}}}{\mathrm{U}-2}}\right)
\end{aligned}
$$

Where $\mathrm{D}_{\mathrm{nssm}}=$ the chloride migration coefficient, $\left(\times 10^{-12} \mathrm{~m}^{2} / \mathrm{s}\right), \mathrm{Tsm}=$ the average value of the initial and final temperatures in the anolyte $(\mathrm{NaOH}$ solution), $\left({ }^{\circ} \mathrm{C}\right), \mathrm{U}=$ the absolute value of the applied voltage, (V), $\mathrm{L}=$ the thickness of the specimen, $(\mathrm{mm}), \mathrm{t}=$ the test duration, (hour), and $x_{d}=$ the average value of the chloride ion penetration depths, ( $\mathrm{mm})$.

\section{RESULTS AND DISCUSSION}

\subsection{Density}

The density results for the high-strength $\mathrm{CT}$ concrete and RAC are given in Figure 5. At 90 days, the density of CT concrete was $2450 \mathrm{~kg} / \mathrm{m}^{3}$, and the density of RA concrete was $2250 \mathrm{~kg} / \mathrm{m}^{3}$; the difference is approximately $8 \%$ lower than the of CT concrete 


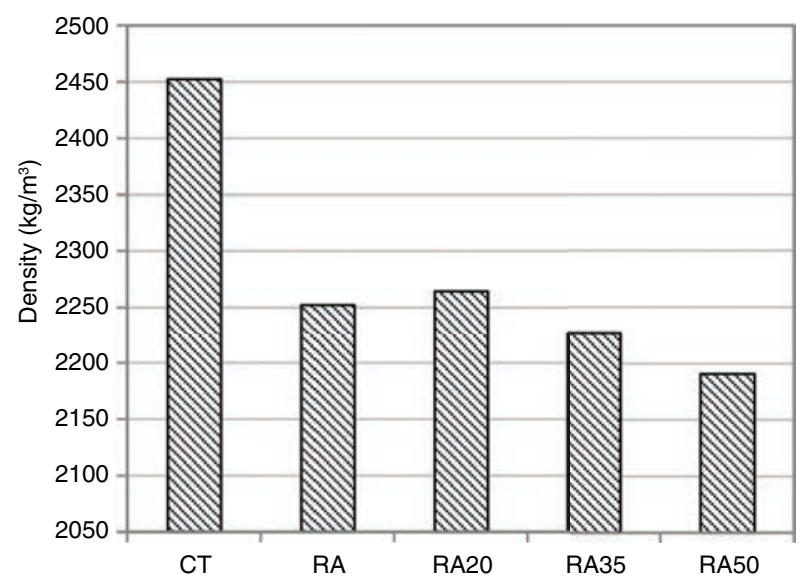

FIGURE 5. Density of $\mathrm{CT}$ and recycled aggregate concretes.

when the recycled coarse aggregate was used as a replacement for crushed limestone. The lower density of the RA concrete was due to the old cement paste or mortar attached to the surface texture of the original aggregate, which had a lower SG (2.45) than that of crushed limestone (2.71). Therefore, it was expected that by substituting the crushed limestone with recycled coarse aggregate, the concrete's density would be lower. The results were similar to those in Safiuddin et al. (34) and Khoshkenari et al. (35).

The partial substitution of GBA for OPC had a slight influence on the density of the RAC. The RA20 and RA35 concretes had densities of 2265 and $2225 \mathrm{~kg} / \mathrm{m}^{3}$, respectively, which were close to that of the RA concrete without GBA. However, the use of GBA to substitute $50 \%$ wt of binder resulted in the reduced density of $2185 \mathrm{~kg} / \mathrm{m}^{3}$ for RA50, which was approximately 3\% lower than the density of the RA concrete. It was clearly observed that the high amount of GBA replacement of OPC by weight led to an increase in paste volume, from which the density of GBA was made to be lower than that of OPC (see Table 1), resulting in the lower density of the RA50 concrete.

\subsection{Permeable Pore Space}

Figure 6 shows the volumes of permeable pore space (\%void) of the CT concrete and recycled aggregate concretes. The \%void of the CT and RA concretes were 6.80 and $12.69 \%$, respectively, and it could be observed that the \%void of concrete increased when the crushed limestone was replaced with RCA in the concrete. The higher \%void of the RA concrete was due to the high porosity of the old mortar or cement paste adhered to the surface of the RCA, which was approximately 8 times higher than that of the crushed limestone.

In case of the RAC containing GBA, the RA20, RA35 and RA50 concretes had \%void values of 12.43 ,

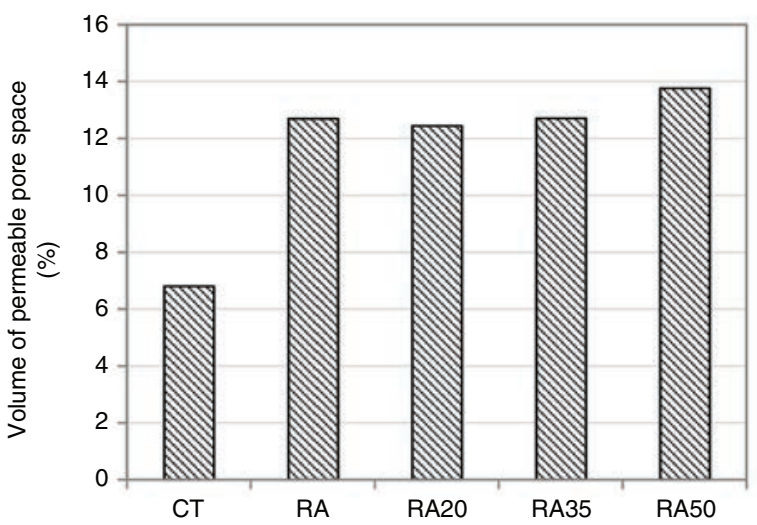

FIgURE 6. Volume of permeable pore space of CT and recycled aggregate concretes.

12.70 and $14.16 \%$, respectively. Replacing OPC with 20 and $35 \%$ of GBA had a slight effect on the porosity of the RA concrete. However, when $50 \%$ GBA was incorporated, the \%void of the RA50 concrete further increased. This may be related to the fact that adding a large amount of GBA led to a reduction in the cement content in the concrete, and the $\mathrm{Ca}(\mathrm{OH})_{2}$ produced by the hydration reaction of the OPC was not sufficient to allow the pozzolanic reaction with the silica and alumina oxides from the GBA. Therefore, the porosity of RA50 concrete increased, and the results are analogous to those of the concrete made with other pozzolanic materials $(36,37)$.

\subsection{Compressive Strength}

The relationship between compressive strength and curing age for the CT concrete and RAC is presented in Figure 7. At 7, 28 and 90 days, the compressive strengths of the CT concrete were 57, 62 and $70 \mathrm{MPa}$, respectively. Meanwhile, the RA concrete had compressive strengths of 58, 63 and 69 $\mathrm{MPa}$, or approximately 101, 102 and $99 \%$ of the CT concrete at 7, 28 and 90 days, respectively. The normalized compressive strengths of RAC compared to the CT concrete are given in Figure 8. It can be observed from Figs. 7 and 8 that RAC made with RCA obtained approximately the same strength as the corresponding CT concrete. The slightly greater strength of the RA concrete relative to the CT concrete may be attributed to a stronger bond developed at the ITZ between the old mortar and the original aggregate of RAC (which was obtained from the concrete with the compressive strength of approximately $50 \mathrm{MPa}$ ) (38-40); therefore, the strengthcontrolling link of the RA concrete was the ITZ between the new mortar and the RCA, where the interfacial bond was the weakest phase in the concrete. These results are similar to those in previous studies $(41,42)$. Moreover, the TSMA $\mathrm{p}_{2}$ procedure 


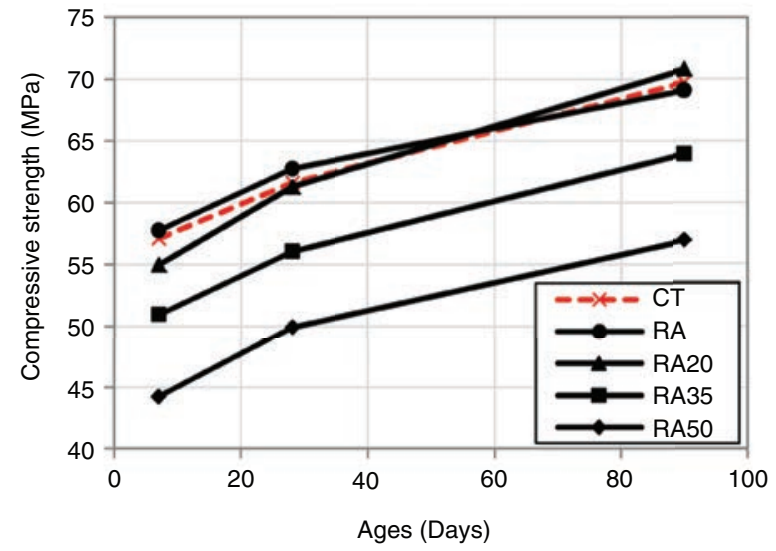

FIGURE 7. Relationship between the compressive strength and curing age of concretes.

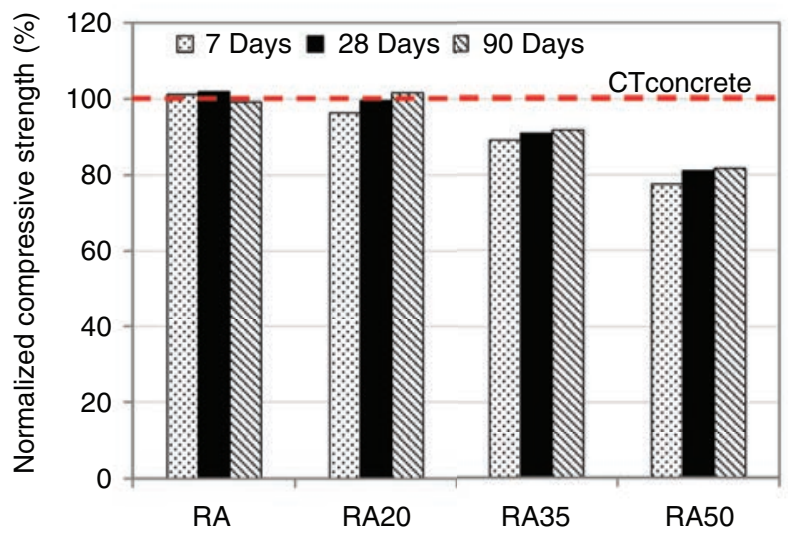

FIGURE 8. Normalized compressive strength of recycled aggregate concrete compared with conventional concrete (CT concrete).

could have improved the weaker link at the ITZ of the RAC, which led to increase in the strength of the concrete (14).

For RAC with GBA at the early ages, an increase in GBA replacement reduced the compressive strengths of those concretes. For instance, at 7 days, the compressive strengths of RA20, RA35 and RA50 concretes were 55, 50.9 and $44.2 \mathrm{MPa}$, or 96,89 and $77 \%$ of the CT concrete, respectively, whereas the compressive strengths of the concretes at 28 days were $61.3,56$ and $49.9 \mathrm{MPa}$, or 99,91 and $81 \%$ that of the CT concrete, respectively. At the early ages (before 28 days), the concrete strength due to the hydration reaction (between cement and water) was greater than the strength gained from pozzolanic reaction. When GBA was used as a substitute for OPC in the concrete, the amount of OPC in the mixture was reduced, leading to a reduction in the hydration reaction. However, when the OPC was partially replaced by $20 \% \mathrm{GBA}$, there was greater compressive strength than for the CT concrete at the later ages (90 days or more). For example, at 90 days, the RA20 concrete had a compressive strength of $70.8 \mathrm{MPa}$, or $102 \%$ of the CT concrete. The results indicate that BA with elevated fineness is a good reactive pozzolanic material and can be used as a mineral admixture to improve the strength of RAC. On the contrary, RAC mixtures having 35 and $50 \%$ replacement levels of GBA (RA35 and RA50 concretes) developed less compressive strength than the CT concretes. The lower strength development of the RA35 and RA50 concretes was attributed to the pozzolanic reaction being produced to a lesser extent due to the lower amount of calcium hydroxide as a consequence of the low content of Portland cement in the concrete (43).

The relationship between the density and the compressive strength of the CT concrete and RAC is presented in Figure 9. At the same compressive strength, the density of CT concrete was higher than that of RAC with and without GBA. For instance, at the compressive strength of $70 \mathrm{MPa}$, the density of RAC was approximately $2255 \mathrm{~kg} / \mathrm{m}^{3}$, which was approximately $8 \%$ lower than that of CT concrete (with a density of approximately $2450 \mathrm{~kg} / \mathrm{m}^{3}$ ). In addition, the compressive strength increased as when the density of the RAC increased. A prospective study indicated that the RAC had densities between 2180 to $2280 \mathrm{~kg} / \mathrm{m}^{3}$, corresponding to compressive strengths of between 56 and $72 \mathrm{MPa}$.

Figure 10 presents the relationship between the $\%$ void and the compressive strength of the CT concrete and the RAC. In the figure, the data were divided into two groups. The first group (the conventional concrete group) was the concrete using NA, and the data were obtained from Rukzon and Chindaprasirt (24) and plotted, including a comparative analysis with the results of this group. The second group (the RAC group) was the concrete using RCA with and without GBA. The results showed that the RAC with and without GBA had higher

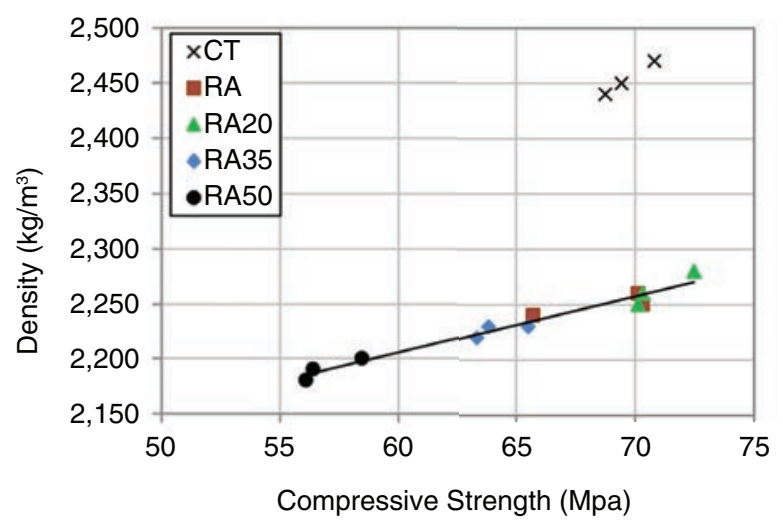

Figure 9. Relationship between the density and the compressive strength of concrete. 


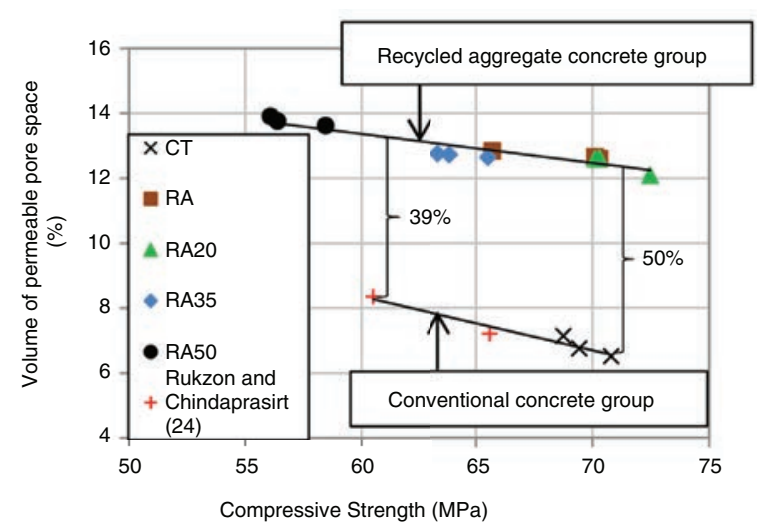

FIGURE 10. Relationship between the volume of permeable pore space and the compressive strength of concrete.

$\%$ void than that of the conventional concretes at the same compressive strength. For the concrete compressive strengths between 61 and $72 \mathrm{MPa}, \mathrm{RAC}$ with and without GBA had a higher \%void than the conventional concrete by approximately $39-50 \%$. However, the reduction in the $\%$ void of the concrete enhanced the compressive strength of all concrete groups (conventional concrete and RAC with and without GBA). It was noted that there was a direct relationship between \%void and the compressive strength of concrete for each group.

\subsection{Depth of Chloride Ion Penetration}

A migration test was carried out, and the chloride ion penetration depth was measured by spraying the fresh fracture surfaces of the specimen with an $\mathrm{AgNO}_{3}$ solution. Each result represents the average of three samples. The depths of chloride ion penetration into $\mathrm{CT}$ concrete is presented in Figure 11, while Figure 12 shows the relationship between the depth of chloride ion penetration and the replacement level of GBA for the RA concretes. At 28 days, the depths of chloride ion penetration into CT and RA concretes were 16.3 and $21.9 \mathrm{~mm}$, respectively, and decreased to 14.9 and $20.5 \mathrm{~mm}$, respectively, at 90 days. Apparently, replacing the crushed limestone with RCA had a negative impact on the chloride resistance of the concretes. Crushed limestone presents impermeable inclusion and therefore is an obstacle to chloride ingress (44) (as shown in Figure 13a), while the porosities of the attached old mortar of the RCA facilitate chloride ion penetration (as shown in Figure 13b). This can explain why the reason why chloride ingress in RA concrete is high compared with CT concrete.

The use of GBA as a binder to replace OPC had a clear positive influence on the durability of RAC in terms of the resistance of chloride ion penetration. This result gave the same results with concretes containing NA $(24,26)$. Considering the results of chloride ion penetration into RAC (as shown in Figures 11 and 12), the depths of chloride ion penetration for the RA20, RA35 and RA50 concretes (GBA replacement levels of 20,35 and $50 \%$, respectively) were $20,14.7$ and $13.3 \mathrm{~mm}$ at the age of 28 days, which was approximately 9,33 and $40 \%$ lower than that of the RA concrete, respectively, and decreased to $14.9,9.2$ and $7.7 \mathrm{~mm}$ at the age of 90 days, which was approximately 27,55 and $62 \%$ lower than that of the RA concrete, respectively. This indicates that increasing the GBA replacement levels resulted in an increase of the resistance of RAC due to chloride ion penetration. Moreover, at high GBA content (i.e., 35 and $50 \%$ replacement), the depths of chloride ion penetration into RA35 and RA50 concretes were lower than for the CT concrete at a similar age, although the compressive strengths of RA35 and RA50 were lower. This is due to the filler effect, in which the small particles of GBA fill in the space between the cement particles, resulting in a much denser binder. In addition, the pozzolanic products

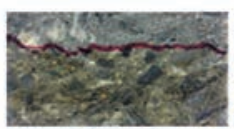

CT

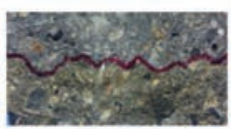

RA

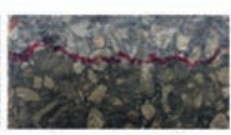

RA20

(a) 28 days
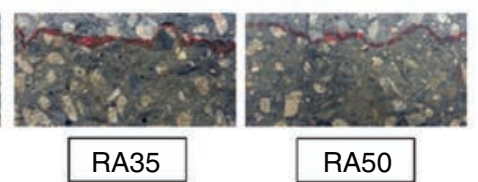

RA50

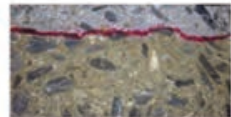

CT

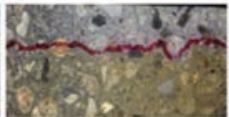

RA

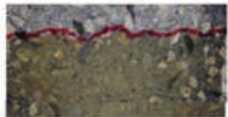

RA20

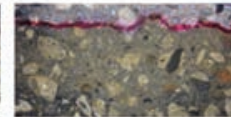

RA35

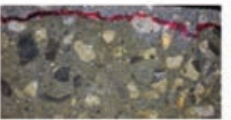

RA50

(b) 90 days

FIGURE 11. Depth of chloride penetration into concrete: a) 28 Days, b) 90 Days. 


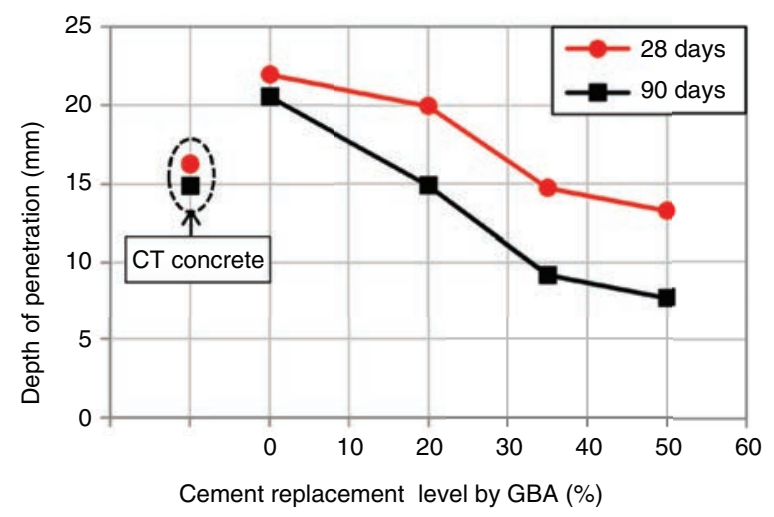

FIGURE 12. Relationship between the depth of chloride penetration and the replacement level of GBA for RA concretes.

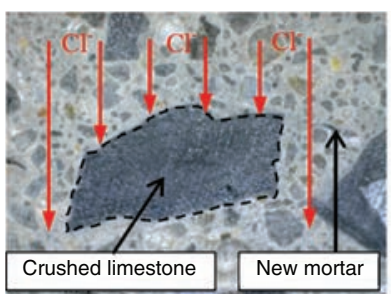

(a) Crushed limestone

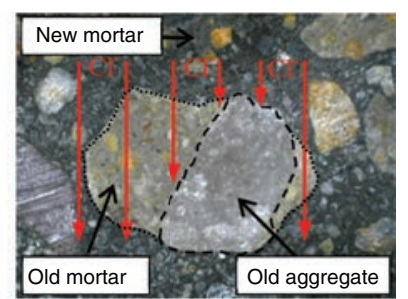

(b) Recycled coarse aggregate
FIGURE 13. Chloride ion penetration into concrete containing: a) crushed limestone, b) recycled coarse aggregate.

(CSH and CAH) from GBA were responsible for physical binding, by which chloride ions may be physically adsorbed on the surfaces of those products $(45,46)$. Thus, GBA is considered to inhibit the chloride ions from penetrating deeper into concrete containing RCA.

The effect of GBA content on the percentage decrease in the depth of chloride ion penetration and the percentage increase in the compressive strength of concrete at 28 to 90 days is presented in Figure 14. It can be seen that the compressive strength had a small influence on decreasing the chloride ion penetration into RAC, while the GBA replacement value had a larger influence on reducing the infiltration of chloride ions into concrete. For example, the increase in compressive strength for the RA concrete was $9 \%$, and the decrease in the depth of chloride ion penetration was $6 \%$. Replacing OPC with 20,35 and 50\% (by weight of binder) of GBA yielded increases in compressive strength of 16,15 and $14 \%$, respectively, while the decreases in the depth of chloride ion penetration were 25,38 and $42 \%$, respectively. This confirmed the result regarding the improvement of durability in RAC with respect of chloride resistance, demonstrating that replacing OPC with GBA was more effective than the increase in the compressive strength.

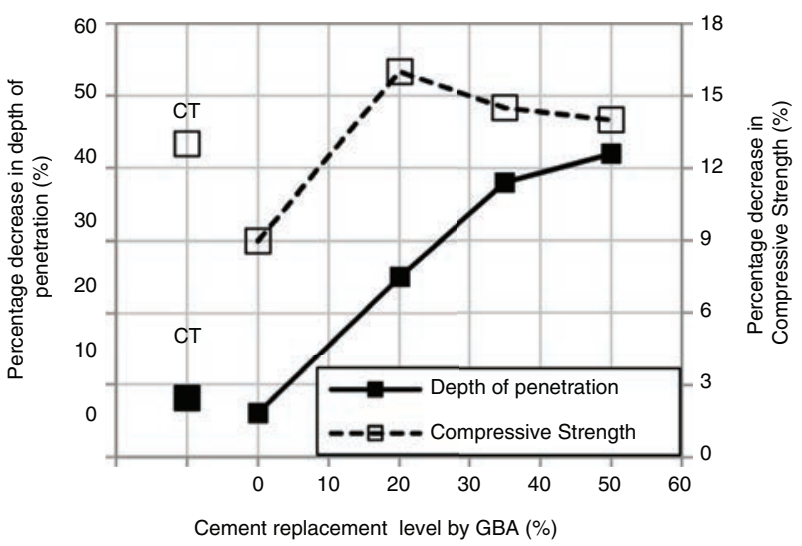

Figure 14. Percentage decrease in the depth of chloride penetration and the percentage increase in the compressive strength of concrete at the ages of 28 to 90 days.

\subsection{Chloride Migration Coefficient}

The chloride migration coefficient $\left(\mathrm{D}_{\text {nssm }}\right)$ after the migration test was calculated using equation [3] as per NT Build 492 (31), for which the applied constant electrical potentials of $60 \mathrm{~V}$ with $18 \mathrm{~h}$ were used. The results of the chloride migration coefficient are demonstrated in Figure 15. The chloride migration coefficients at 28 days for the CT and RA concretes were $5.45 \times 10^{-12}$ and $7.29 \times 10^{-12} \mathrm{~m}^{2} / \mathrm{s}$, respectively. At the age of 90 days, the CT and RA concretes had chloride migration coefficients of $5.01 \times 10^{-12}$ and $6.91 \times 10^{-12} \mathrm{~m}^{2} / \mathrm{s}$, respectively. It can be seen that the low quality of the RCA, which had a higher porosity than crushed limestone (also see Table. 3), resulted in a low resistance to chloride ion penetration into RAC. This result is consistent with the findings of Ying et al. (47), who reported that the attached old mortar content had a great influence on chloride ion diffusion into RAC. As expected, the RA concrete had a higher chloride migration coefficient than the $\mathrm{CT}$ concrete at the same testing ages.

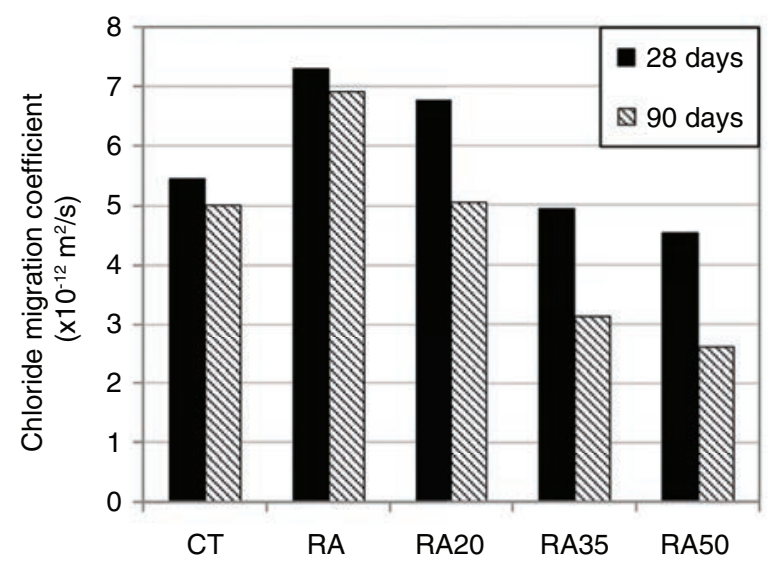

FIGURE 15. Chloride migration coefficient of concrete. 
However, RAC with GBA showed good resistance to chloride ion penetration compared to conventional concrete using crushed limestone and an increased chloride resistance for RAC with increased GBA replacement. Moreover, the chloride migration coefficients of the RA concretes containing GBA as a cement replacement of 35 and $50 \%$ were lower than that of CT concrete at similar ages. The chloride migration coefficient at 28 days for the RA20, RA35 and RA50 concretes were $6.76 \times 10^{-12}, 4.93 \times 10^{-12}$ and $4.54 \times 10^{-12} \mathrm{~m}^{2} / \mathrm{s}$, respectively, and they decreased to $5.04 \times 10^{-12}, 3.12 \times 10^{-12}$ and $2.61 \times 10^{-12} \mathrm{~m}^{2} / \mathrm{s}$, respectively, at the age of 90 days. Similar results had been reported for studies on the non-steady-state migration coefficients of concrete (48), where the use of fly ash up to $20 \%$ of OPC replacement was found to have lower chloride migration coefficients at later ages and at higher cement replacement levels. These results confirm that the pozzolanic reaction products provide the RA concretes containing GBA with protection against chloride ion penetration.

Figure 16 present the results of the compressive strength and chloride migration coefficients of concrete. The compressive strength of concrete affected the chloride ion penetration resistance, especially the RAC with GBA. For instance, the RA and RA20 concretes at 28 days had compressive strengths of 63 and $61 \mathrm{MPa}$, and the chloride migration coefficients were $7.29 \times 10^{-12}$ and $6.76 \times 10^{-12} \mathrm{~m}^{2} / \mathrm{s}$, respectively, whereas at later age (90 days), the RA and RA20 concretes had compressive strengths of 69 and $71 \mathrm{MPa}$, and the chloride migration coefficients were $6.91 \times 10^{-12}$ and $5.04 \times 10^{-12} \mathrm{~m}^{2} / \mathrm{s}$, respectively. Nevertheless, the GBA replacement levels in RAC had a great influenced on the chloride ion resistance compared to the compressive strength. For instance, the compressive strength of the RA concrete at 90 days was $69 \mathrm{MPa}$ and the chloride

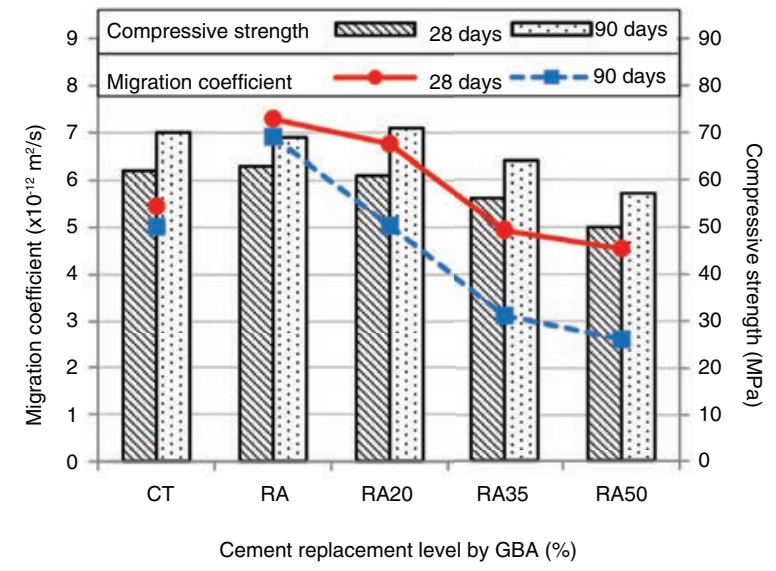

Figure 16. Compressive strength and chloride migration coefficient of concrete. migration coefficient was $6.91 \times 10^{-12} \mathrm{~m}^{2} / \mathrm{s}$, whereas the RA20, RA35 and RA50 concretes had compressive strengths of 71, 64 and $57 \mathrm{MPa}$ and the chloride migration coefficients were $5.04 \times 10^{-12}, 3.12 \times 10^{-12}$ and $2.61 \times 10^{-12} \mathrm{~m}^{2} / \mathrm{s}$, respectively.

\section{CONCLUSIONS}

Based on the results of the properties of highstrength concrete (HS-C) containing recycled concrete aggregate (RCA) with ground bagasse ash (GBA) are summarized as follows:

1. The use of RCA as a full replacement for crushed limestone in concrete resulted in a higher volume of permeable pore space, lower density, and lower resistance to chloride ion penetration compared to CT concrete. However, RCA, which was obtained from high-quality concrete (with a compressive strength of approximately $50 \mathrm{MPa}$ ), had little or no effect on the compressive strength of the concrete.

2. Decreased density and an increased \%void of RAC were observed when a high replacement value of GBA, up to $50 \% \mathrm{wt}$ of binder, was used.

3. Using GBA as a $20 \%$ wt replacement for OPC caused the compressive strength of the RAC to be higher than that of CT concrete at later ages (90 days or more). Additionally, RAC containing up to $50 \%$ of GBA exhibited compressive strength in the range of 57 to $71 \mathrm{MPa}$, which was higher than the HS-C requirement specified in ACI 363R (49) (55 MPa).

4. The utilization of GBA for up to $50 \%$ of cement replacement was particularly effective in reducing chloride ion penetration into RAC, although that concrete had lower compressive strength than the conventional concrete. It was also found that using GBA in RAC had a great influence on the chloride ion penetration resistance compared to the compressive strength.

5. This experiment suggested that RCA (obtained from high-quality concrete) and GBA (up to $50 \%$ wt of binder) can be used as raw materials to produce HS-C. In addition, the results clearly showed that high GBA contents (35 and 50\%wt of binder replacement) led to an increase in chloride resistance for HS-RAC, with compressive strengths over $80 \%$ relative to the control concrete.

\section{ACKNOWLEDGMENTS}

The authors gratefully acknowledge the financial supports from the Office of the Higher Education Commission, Thailand, supporting this work under the Strategic Scholarships Fellowships Frontier Research Networks (specific for Thailand's southern 
region) for the Ph.D. program Thai Doctoral degree program and supporting this work under the Institutional Research Capability Development Grant from the Thailand Research Fund (TRF) and King Mongkut's University of Technology Thonburi. Thanks are also extended to Khon Kaen University and the Thailand Research Fund (TRF) under the TRF Senior Research Scholar Grant No. RTA5780004.

\section{REFERENCES}

1. Sata, V.; Jaturapitakkul, C.; Kiattikomol, K. (2007) Influence of pozzolan from various by-product materials on mechanical properties of high-strength concrete. Constr. Build. Mater. 21 [7], 1589-1598. https://doi.org/ 10.1016/i.conbuildmat.2005.09.011.

2. Nath, P.; Sarker, P. (2011) Effect of Fly Ash on the Durability Properties of High Strength Concrete. Procedia Eng. 14, 1149-1156. https://doi.org/10.1016/j.proeng.2011.07.144.

3. Tangchirapat, W.; Jaturapitakkul, C.; Chindaprasirt, P. (2009) Use of palm oil fuel ash as a supplementary cementitious material for producing high-strength concrete. Constr. Build. Mater. 23 [7], 2641-2646. https://doi. org/10.1016/j.conbuildmat.2009.01.008.

4. Katz, A. (2003) Properties of concrete made with recycled aggregate from partially hydrated old concrete. Cement Concrete Res. 33 [5], 703-711. https://doi.org/10.1016/ S0008-8846(02)01033-5.

5. Prince, M.J.R.; Singh, B. (2013) Bond behaviour of deformed steel bars embedded in recycled aggregate concrete. Constr. Build. Mater. 49, 852-862. https://doi.org/ 10.1016/j.conbuildmat.2013.08.031

6. Evangelista, L.; de Brito, J. (2010) Durability performance of concrete made with fine recycled concrete aggregates. Cem. Concr. Comp. 32 [1], 9-14. https://doi.org/10.1016/j. cemconcomp.2009.09.005.

7. Haitao, Y.; Shizhu, T. (2015) Preparation and properties of high-strength recycled concrete in cold areas. Mater. Construcc. 65 [318], e050. https://doi.org/10.3989/ mc.2015.03214

8. Srubar Iii, W.V. (2015) Stochastic service-life modeling of chloride-induced corrosion in recycled-aggregate concrete. Cem. Concr. Comp. 55, 103-111. https://doi.org/10.1016/j. cemconcomp.2014.09.003.

9. Fernández-Ledesma, E.; Jiménez, J.R.; Ayuso, J.; Corinaldesi, V.; Iglesias-Godino, F.J. (2016) A proposal for the maximum use of recycled concrete sand in masonry mortar design. Mater. Construcc. 66 [321] e075. https://doi. org/10.3989/mc.2016.08414.

10. González-Taboada, I.; González-Fonteboa, B.; MartínezAbella, F.; Carro-López, D. (2016) Study of recycled concrete aggregate quality and its relationship with recycled concrete compressive strength using database analysis. Mater. Construcc. 66 [323], e089. https://doi.org/10.3989/ mc.2016.06415.

11. Padmini, A.K.; Ramamurthy, K.; Mathews, M.S. (2009) Influence of parent concrete on the properties of recycled aggregate concrete. Constr. Build. Mater. 23 [2], 829-836. https://doi.org/10.1016/j.conbuildmat.2008.03.006

12. Purushothaman, R.; Amirthavalli, R.R.; Karan, L. (2015) Influence of Treatment Methods on the Strength and Performance Characteristics of Recycled Aggregate Concrete. J. Mater. Civ. Eng. 27 [5], 04014168. https://doi. org/10.1061/(ASCE)MT.1943-5533.0001128.

13. Sánchez-Roldán, Z.; Martín-Morales, M.; ValverdePalacios, I.; Valverde-Espinosa, I.; Zamorano, M. (2016) Study of potential advantages of pre-soaking on the properties of pre-cast concrete made with recycled coarse aggregate. Mater. Construcc. 66 [321], e076. https://doi. org/10.3989/mc.2016.01715.
14. Tam, V.W.Y; Gao, X.F.; Tam, C.M. (2006) Comparing performance of modified two-stage mixing approach for producing recycled aggregate concrete. Mag Concrete. Res. 58 [7], 477-484. https://doi.org/10.1680/macr.2006.58.7.477.

15. Limbachiya, M.; Meddah, M.S.; Ouchagour, Y. (2012) Use of recycled concrete aggregate in fly-ash concrete. Constr Build. Mater. 27 [1], 439-449. https://doi.org/10.1016/j. conbuildmat.2011.07.023.

16. Kroehong, W.; Damrongwiriyanupap, N.; Sinsiri, T.; Jaturapitakkul, C. (2016) The Effect of Palm Oil Fuel Ash as a Supplementary Cementitious Material on Chloride Penetration and Microstructure of Blended Cement Paste. Arab. J. Sci. Eng. 41 [12], 4799-4808. https://doi.org/ 10.1007/s13369-016-2143-1.

17. Chindaprasirt, P.; Chotithanorm, C.; Cao, H.T.; Sirivivatnanon, V. (2007) Influence of fly ash fineness on the chloride penetration of concrete. Constr. Build. Mater. 21 [2], 356-361. https://doi.org/10.1016/j. conbuildmat.2005.08.010.

18. Gastaldini, A.L.G.; da Silva, M.P.; Zamberlan, F.B.; Mostardeiro Neto, C.Z. (2014) Total shrinkage, chloride penetration, and compressive strength of concretes that contain clear-colored rice husk ash. Constr Build Mater. 54, 369-377. https://doi.org/10.1016/j.conbuildmat.2013.12.044.

19. Awal, A.S.M.A.; Shehu, I.A. (2013) Evaluation of heat of hydration of concrete containing high volume palm oil fuel ash. Fuel. 105, 728-731. https://doi.org/10.1016/j. fuel.2012.10.020.

20. Chalee, W.; Ausapanit, P.; Jaturapitakkul, C. (2010) Utilization of fly ash concrete in marine environment for long term design life analysis. Mater. Des. 31 [3], 12421249. https://doi.org/10.1016/j.matdes.2009.09.024.

21. Cordeiro, G.C.; Toledo Filho, R.D; Tavares, L.M.; Fairbairn, E.M.R. (2008) Pozzolanic activity and filler effect of sugar cane bagasse ash in Portland cement and lime mortars. Cement. Concrete. Comp. 30 [5], 410-418. https://doi.org/10.1016/j.cemconcomp.2008.01.001.

22. Martirena Hernández, J.F.; Middendorf, B.; Gehrke, M.; Budelmann, H. (1998) Use of wastes of the sugar industry as pozzolana in lime-pozzolana binders: study of the reaction. Cement. Concrete. Res. 28 [11], 1525-1536. https://doi.org/10.1016/S0008-8846(98)00130-6.

23. Chusilp, N.; Jaturapitakkul, C.; Kiattikomol, K. (2009) Utilization of bagasse ash as a pozzolanic material in concrete. Constr. Build. Mater. 23 [11], 3352-3358. https://doi. org/10.1016/j.conbuildmat.2009.06.030.

24. Rukzon, S.; Chindaprasirt, P (2012) Utilization of bagasse ash in high-strength concrete. Mater. Des. 34, 45-50. https://doi.org/10.1016/j.matdes.2011.07.045.

25. Chusilp, N.; Jaturapitakkul, C.; Kiattikomol, K. (2009) Effects of LOI of ground bagasse ash on the compressive strength and sulfate resistance of mortars. Constr. Build. Mater. 23 [12], 3523-3531. https://doi.org/10.1016/j. conbuildmat 2009.06.046.

26. Rerkpiboon, A.; Tangchirapat, W.; Jaturapitakkul, C. (2015) Strength, chloride resistance, and expansion of concretes containing ground bagasse ash. Constr. Build. Mater. 101, Part 1, 983-989. https://doi.org/10.1016/j. conbuildmat.2015.10.140.

27. ASTM C33/C33M. (2013) Standard specification for concrete aggregates. ASTM International. West Conshohocken. PA.

28. ASTM C494/C494M. (2013) Standard specification for chemical admixtures for concrete. ASTM International. West Conshohocken. PA.

29. ASTM C642. (2013) Standard test method for density, absorption, and voids in hardened concrete. ASTM International. West Conshohocken. PA

30. ASTM C39/C39M. (2015) Standard test method for compressive strength of cylindrical concrete specimens. ASTM International. West Conshohocken. PA.

31. NT Build 492. (1999) Concrete, mortar and cement-based repair materials: chloride migration coefficient from nonsteady-state migration experiments. Nordtest Building Method. Espoo. FL. 
32. AASHTO TP64-03. (2007) Standard method of test for predicting chloride penetration of hydraulic cement concrete by the rapid migration procedure. American Association of State Highway and Transportation Officials, Washington, D.C.

33. Otsuki, N.; Miyazato, S.I.; Yodsudjai, W. (2003) Influence of Recycled Aggregate on Interfacial Transition Zone, Strength, Chloride Penetration and Carbonation of Concrete. J. Mater. Civ. Eng. 15 [5], 443-451. https://doi. org/10.1061/(ASCE)0899-1561(2003)15:5(443).

34. Safiuddin, M.; Alengaram, U.J.; Rahman, M.M.; Salam, M.A.; Jumaat, M.Z. (2013) Use of recycled concrete aggregate in concrete: a review. J. Civ. Eng. Manag. 19 [6], 796-810. https://doi.org/10.3846/13923730.2013.799093.

35. Khoshkenari, A.G.; Shafigh, P.; Moghimi, M.; Mahmud, H.B. (2014) The role of $0-2 \mathrm{~mm}$ fine recycled concrete aggregate on the compressive and splitting tensile strengths of recycled concrete aggregate concrete. Mater. Des. 64, 345-354. https://doi.org/10.1016/j.matdes.2014. 07.048 .

36. Siddique, R.; Singh, K.; Kunal; Singh, M.; Corinaldesi, V.; Rajor, A. (2016) Properties of bacterial rice husk ash concrete. Constr. Build. Mater. 121, 112-119. https://doi. org/10.1016/j.conbuildmat.2016.05.146.

37. Wongkeo, W.; Thongsanitgarn, P.; Ngamjarurojana, A.; Chaipanich, A. (2014) Compressive strength and chloride resistance of self-compacting concrete containing high level fly ash and silica fume. Mater. Des. 64, 261-269. https://doi.org/10.1016/j.matdes.2014.07.042.

38. Li, T.; Xiao, J.; Zhu, C. (2016) Hydration process modeling of ITZ between new and old cement paste. Constr. Build. Mater. 109, 120-127. https://doi.org/10.1016/j. conbuildmat.2016.01.053.

39. Kong, D.; Lei, T.; Zheng, J.; Ma, C.; Jiang, J.; Jiang, J. (2010) Effect and mechanism of surface-coating pozzalanics materials around aggregate on properties and ITZ microstructure of recycled aggregate concrete. Constr. Build. Mater. 24 [5], 701-708. https://doi.org/10.1016/j. conbuildmat.2009.10.038.
40. Poon, C.S.; Shui, Z.H.; Lam, L. (2004) Effect of microstructure of ITZ on compressive strength of concrete prepared with recycled aggregates. Constr. Build. Mater. 18 [6], 461-468. https://doi.org/10.1016/j.conbuildmat.2004.03.005.

41. López Gayarre, F.; López-Colina Pérez, C.; Serrano López, M.A.; Domingo Cabo, A. (2014) The effect of curing conditions on the compressive strength of recycled aggregate concrete. Constr. Build. Mater. 53, 260-266. https://doi. org/10.1016/j.conbuildmat.2013.11.112.

42. Ajdukiewicz, A.; Kliszczewicz, A. (2002) Influence of recycled aggregates on mechanical properties of HS/HPC. Cement. Concrete. Comp. 24 [2], 269-279. https://doi. org/10.1016/S0958-9465(01)00012-9.

43. Lam, L.; Wong, Y.L.; Poon, C.S. (2000) Degree of hydration and gel/space ratio of high-volume fly ash/cement systems. Cement Concrete Res. 30 [5], 747-756. https://doi. org/10.1016/S0008-8846(00)00213-1.

44. Šavija, B.; Luković, M.; Schlangen, E. (2014) Lattice modeling of rapid chloride migration in concrete. Cement Concrete Res. 61-62, 49-63. https://doi.org/10.1016/j.cemconres.2014.04. 004.

45. Jensen, H.U.; Pratt, P.L. (1989) The binding of chloride ions by pozzolanic product in fly ash cement blends. $\mathrm{Adv}$. Cem. Res. 2 [7], 121-129. https://doi.org/10.1680/adcr.1989.2.7.121.

46. Sumranwanich, T.; Tangtermsirikul, S. (2004) A model for predicting time-dependent chloride binding capacity of cement-fly ash cementitious system. Mater. Struct. 37 [6], 387-396. https://doi.org/10.1007/bf02479635.

47. Ying, J.; Xiao, J.; Meng, Q. (2016) On Probability Distribution of Chloride Diffusion Coefficient for Recycled Aggregate Concrete. Int. J. Concr. Struct. Mater. 10 [1], 61-73. https://doi.org/10.1007/s40069-015-0123-6.

48. Jain, J.; Neithalath, N. (2011) Electrical impedance analysis based quantification of microstructural changes in concretes due to non-steady state chloride migration. Mater. Chem. Phys. 129 [1-2], 569-579. https://doi.org/10.1016/j. matchemphys.2011.04.057.

49. ACI 363R. (2010) Report on high-strength concrete. American Concrete Institute. Farmington Hills. Michigan. 